\title{
O Brincar na Hospitalização: Possibilidade de Expressão e Mediação de Diferenças
}

\author{
Medeiros, Érica Teixeira de; Figueiredo, Lucia Uchôa \\ Universidade Federal de São Paulo - e_r_i_c_a12@hotmail.com
}

Introdução: o hospital é um local estranho e pouco hospitaleiro para a criança. Sua rotina habitual é alterada, a privacidade é restrita e é submetida a procedimentos dolorosos, gerando angústia e medo. Assim, ela começa a perceber seu entorno como local de dor e sofrimento em que é despersonalizada, sendo desconsiderada sua singularidade e autonomia. Logo, a hospitalização na infância é traumática e pode afetar o desenvolvimento da criança e comprometer sua socialização. Nesta lógica, o brincar insere-se como uma possibilidade de melhorar o bem estar da criança, mediando relações e diluindo diferenças no hospital. a partir da brincadeira, a criança cria um mundo de acordo com sua visão, transforma o brinquedo e o cenário da atividade em um momento lúdico, no qual fantasia, imaginação e realidade se interrelacionam e produzem formas de interpretação e expressão. Objetivo: Observar a criança hospitalizada durante o brincar, analisar segundo aspectos como o fantasiar, a interação e as expressões emocionais e corporais o que é expresso por ela no ambiente hospitalar e demonstrar que o brincar é um fim em si e que compreende uma necessidade infantil essencial para o bem-estar e desenvolvimento da criança no hospital. Metodologia: a pesquisa foi realizada com crianças da ala de oncologia pediátrica e de queimados que participaram do Projeto Baú de Histórias. Proporcionou-se à criança oportunidade de brincar, interagir com outras crianças e fazer uso do faz de conta. a partir da relação com o brincar fornecida pelo projeto, se observou as expressões das crianças, sentimentos externados e as possíveis demandas reveladas. Fez-se uso de um instrumento de coleta de dados com categorias que enquadram possíveis comportamentos suscitados, informações do diagnóstico da criança e a descrição da intervenção, a fim de capturar um retrato pleno da inserção da criança no espaço hospitalar. para fins de análise, foi utilizado o método qualitativo para interpretação dos sentidos dados aos aspectos da vida do sujeito. Resultados: Foi observada uma relativa diferença em relação ao brincar entre as crianças da ala de queimados e da oncologia pediátrica e entre as gravidades dos casos clínicos, conferindo ao ambiente lúdico singulares intervenções, expressões de demandas e adaptação ao ambiente hospitalar. Conclusão: o espaço lúdico promove a socialização e reaviva os conflitos internos e externos os quais a criança vivencia. As intervenções desenvolvidas implantaram um espaço de faz de conta, de exercício de escolhas e papéis, trazendo à criança obrigações imaginárias, atribuição de significados e experiências diversas à realidade, restaurando sua identidade e autonomia. Contudo, em algumas crianças com quadro severo, as visitas tiveram significações menos expressivas, já que os pacientes são regularmente lembrados de sua limitação física pelas dores incessantes e visitas da equipe hospitalar, lembrando-os do mundo real e os distanciando do da fantasia.

Medeiros, Érica Teixeira de; Figueiredo, Lucia Uchôa. O Brincar na Hospitalização: Possibilidade de Expressão e Mediação de Diferenças. In: Anais do Congresso Internacional de Humanidades \& Humanização em Saúde [= Blucher Medical Proceedings, num.2, vol.1]. São Paulo: Editora Blucher, 2014. ISSN 2357-7282

DOI 10.5151/medpro-cihhs-10491 